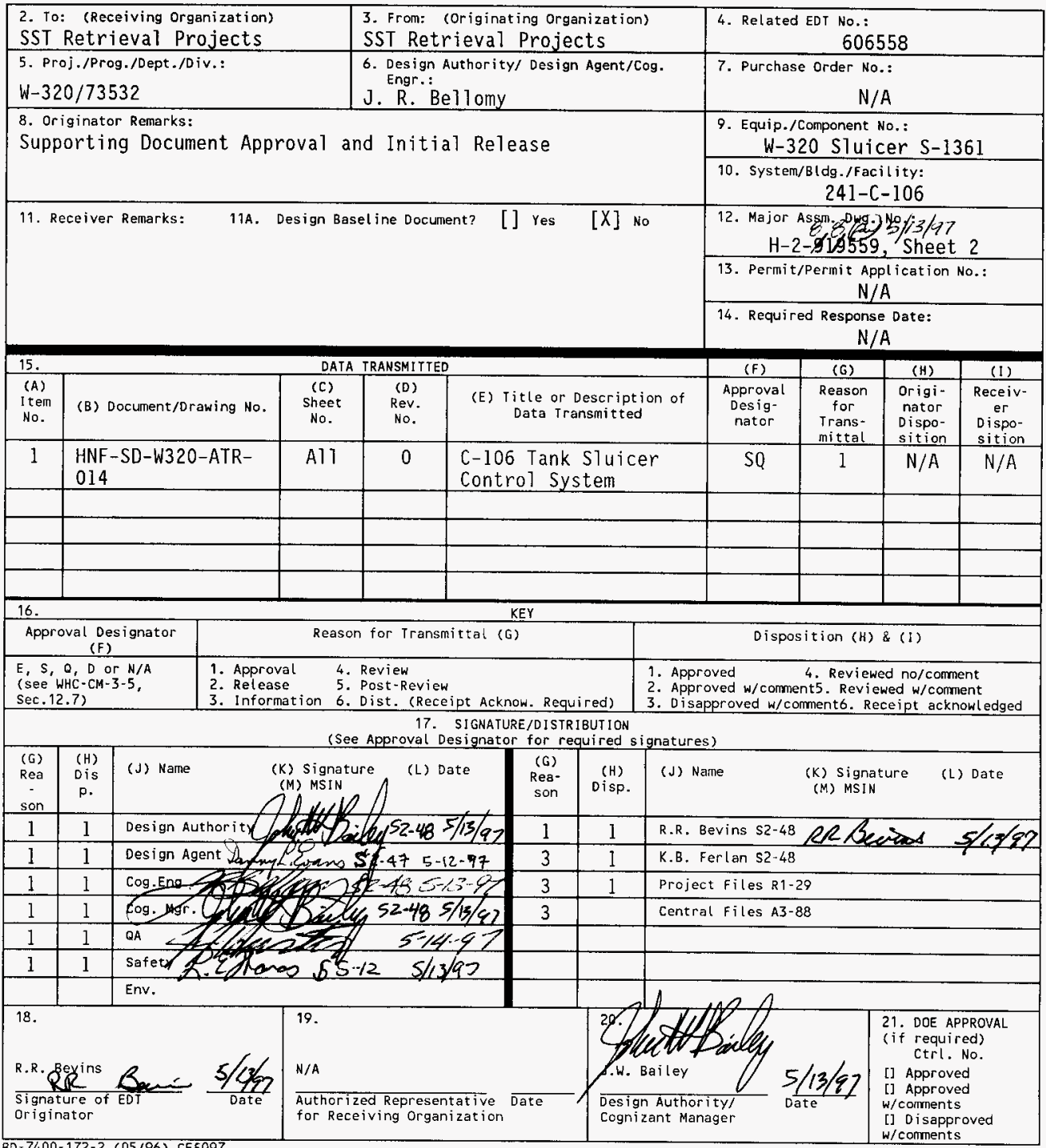




\title{
C-106 Tank Sluicer Control System
}

\author{
J. R. Bellomy
}

SGN Eurisys Services Corporation (SESC), Richland, WA 99352

U.S. Department of Energy Contract DE-AC06-96RL13200
EDT/ECN: 610598
Org Code: $\$ 1100$
B\&R Code: EW3130010
UC: 510
Charge Code: D2MC2
Total Pages: $24>3$ kems $5 / 1,5 / 27$
Key Words: Project W-320, Sluicer Control System $\begin{array}{ll}\text { Abstract: } & \text { Acceptance Test Report for the Sluicer Control system, } \\ & \text { Project } W-320\end{array}$

TRADEMARK DISCLAIMER. Reference herein to any specific comercial product, process, or service by trade name, trademark, manufacturer, or otherwise, does not necessarily constitute or imply its endorsement, recommendation, or favoring by the United States Government or any agency thereof or $i$ ts contractors or subcontractors.

Printed in the United States of Arrerica. To obtain copies of this document, contact: Document Control Services, P.D. Box 950, Mailstop H6-08, Richland WA 99352, Phone (509) 372-2420; Fax (509) 376-4989.
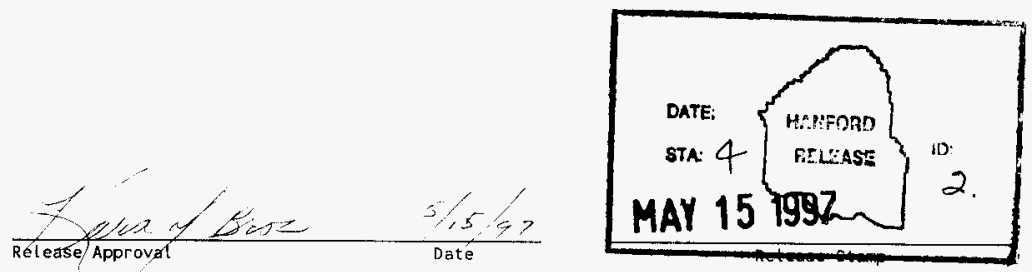

\section{Approved for Public Release}




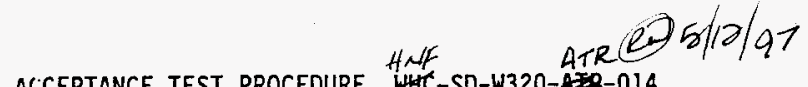

ACCEPTANCE TEST PROCEDURE WHA-SD-W320-A 20-014

TEST TITLE C-106 TANK SLUICER CONTROL SYSTEM

LOCATION C-FARM

PROJECT NUMBER $\mathrm{W}-320$

WORK ORDER ER6159

PROJECT TITLE W-320 Tank 241-C-106 Sluicing

\author{
Prepared By \\ ICF Kajser Hanford Company \\ Richland, Washington \\ For Westinghouse Hanford Company \\ Subcontract WHC-380393
}

PROCEDURE APPROVAL

ICF KAISER HANFORD COMPANY (ICF KH)

Povid A. White

checker

He Phoudhuy

toundertert

Environmental

Shrojuchllly Maragement
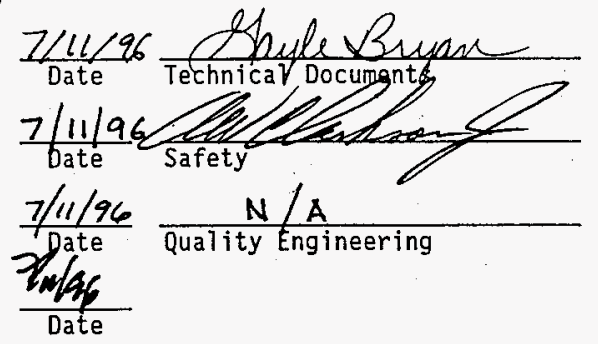

$\frac{N / A}{\text { Quality Engineering }}$

$\frac{7-10-96}{\text { Date }}$

$\frac{7-11-9 C}{\text { Date }}$

Westinghouse Hanford Company (WHC)
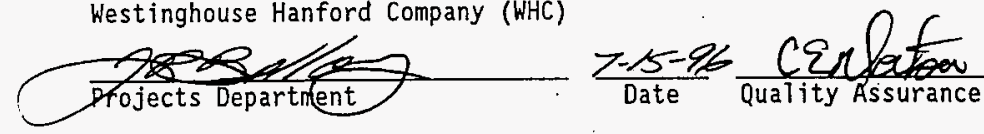

$\frac{7-15-96}{\text { Date }}$

$\frac{N / A}{\text { Safety }}$

$\frac{\text { Paulfauls }}{\text { Date }} \frac{7-16 \cdot 96}{\text { Date }}$ 


\section{EXECUTED BY}

Meibe \& Ramez

Test Director/Organization

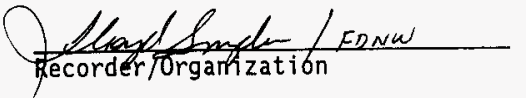

$\frac{4-18-97}{\text { Date }} \frac{\text { Rozzall He Panghy }}{\text { Test Operator/Organization }} \frac{4-18-97}{\text { Date }}$ $\frac{3 / 14 / 47}{\text { Date }}$

\section{WITNESSES}

$\frac{N A}{\text { Witness/Organization }}$

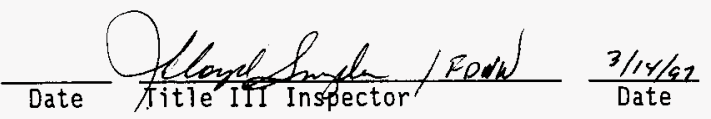

$\frac{\text { NA }}{\text { Witness/Organization }}$

$\frac{\text { NA }}{\text { Witness/Organization }}$

Date

\section{A-E APPROVAL}

ICF Kaiser Hanford Company (ICF KH)

Without

exceptions

Kant. Jengaen

Acceptance inspection

Seme S. Nolw

Project Manager
With exceptions resolved
With exceptions outstanding

TEST APPROVAL AND ACCEPTANCE

Westinghouse Hanford Company
Without
exceptions
With exceptions resolved

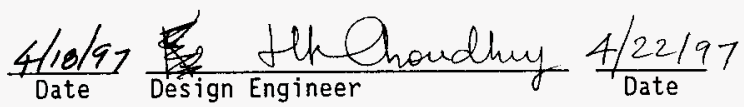
$\frac{4 / 22 / 97}{\text { Date }}$

\section{Pp}

Cano rest erernese

(Title or Department)

RoR. Bevaios

staer-ue mentse

(Title or Department)

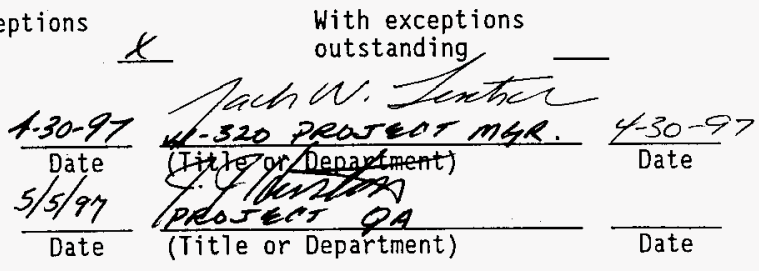

W320014.ATP. 1110

$-2-$

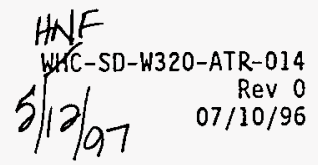


TITLE/PROCEDURE APPROVAL

EXECUTION AND TEST APPROVAL 2

TABLE OF CONTENTS 3

PURPOSE

REFERENCES

RESPONSIBILITIES * 4

CHANGE CONTROL

EXECUTION

EXCEPTIONS

PREREQUISITES, EQUIPMENT/INSTRUMENTS, AND ABBREVIATIONS 8

8

SLUICER HYDRAULIC CONTROL UNIT SHC-1361 ELECTRICAL SERVICE

NOTE: At completion of test, enter pages added during performance of test to this Table of Contents.

Exceptions 
1 PURPOSE

This Acceptance Test Procedure (ATP) has been prepared to demonstrate that the C-Farm tank C-106 sluicer functions as required by the design criteria.

2 REFERENCES

2.1 DRAWINGS

$\mathrm{H}-2-818523$, Sh 1 , Rev 0 H-2-818559, Sh 2, Rev 0 $\mathrm{H}-2-818680$, Sh 1, Rev 0 $\mathrm{H}-2-818681$, Sh 1-3, Rev 0 H-2-818591, Sh 1-4, Rev 1 H-2-818674, Sh 1-2, Rev 0 $\mathrm{H}-2-818675$, Sh 6 , Rev 0 $\mathrm{H}-2-818702$, Sh 1-2, Rev 0
Sluice Pit C-06C Plan, Sections \& Details Project $W-320 P$ \& ID Tank 241-C-106

C-Farm One-Line Diagram

C-Farm Elect Equip Skid Details

Sluicing Cabinet CB-01

C-Farm Conduit Plan

C-Farm Elem Diagrams

C-Farm Sluice Pit DETAILS

2.2 SPECIFICATIONS

Construction Specification $W-320-C 5$, Rev 0

2.3 ENGINEERING CHANGE NOTICES (ECNS)

Prior to final test approval, mark up the controlled copy of this ATP with all of the ECNs written against it.

2.4 VENDOR INFORMATION

Vendor Information \#22668, W-320-P20: SLUICER, HYDRAULIC DRIVE AND CONTROLS, 01 ympic Toot \& Engineering

3 RESPONSIBILITIES

3.1 GENERAL

Each company or organization participating in this ATP will designate personnel to assume the responsibilities and duties as defined herein for their respective roles. The designees shall become familiar with this ATP and the systems involved to the extent that they can perform their assigned duties.

3.2 WHC PROJECT ENGINEER

3.2.1 Signs Execution and Test Approval page when test is complete and accepted.

3.2.2 Provides a distribution list for the approved and accepted ATP.

3.3 ICF KH PROJECT MANAGER

3.3.1 Designates a Test Director.

3.3.2 Signs Execution and Test Approval page when test is complete and accepted.

W320014.ATP. 1110

$-4-$

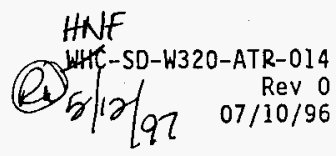


3.3.3 Signs exception form when all exceptions have been resolved.

\subsection{TEST DIRECTOR}

3.4.1 Coordinates and directs acceptance testing.

3.4.2 Coordinates testing with ICF KH Utilities.

3.4.3 Coordinates testing with ICF KH Craft.

3.4.4 Before start of test, obtains all outstanding ECNs against referenced documents of Section 2, and distributes the approved testing schedule to ICF KH Project Manager and WHC Project Engineer.

3.4.5 Notifies concerned parties (includes ICF KH Project Manager, ICF KH Principal Lead Engineer, and WHC Project Engineer) when a change is made in the testing schedule.

3.4.6 Schedules and conducts a pretest kickoff meeting with test participants when necessary.

3.4.7 Confirms that field testing and inspection of the system or portion of the system to be tested has been completed.

3.4.8 Stops any test which, in his or her judgement, may cause damage to the system until the problem has been resolved.

3.4.9 After verifying there is no adverse impact, may alter the sequence in which systems or subsystems are tested.

3.4.10 If a test is to be suspended for a period of time, ensures that the system is left in a safe mode.

3.4.11 Before restarting suspended test, reverifies the test prerequisites.

3.4.12 Initiates ECNs to document required changes to the ATP.

3.4.13 Reviews recorded data, discrepancies, and exceptions.

3.4.14 Signs Execution and Test Approval page when test has been performed.

3.4.15 Takes necessary actions to clear exceptions to the test, and signs exception form when exceptions have been resolved.

3.4.16 Obtains required signatures on the ATP Master before reproduction and distribution.

3.5 WITNESSES (Provided by Participating Organizations. One witness shall be a Title III acceptance inspector.)

3.5.1 Witnesses the tests.

3.5.2 Reviews results of testing.

3.5.3 Assists the Test Director when requested. 
3.5.4 Signs Execution and Test Approval page when test has been performed.

3.5.5 Signs exception form when exception has been resolved.

3.6 RECORDER (Provided by ICF KH)

3.6.1 Prepares a field copy from the ATP Master.

3.6.2 Records names of all designated personnel on field copy of ATP before start of testing.

3.6.3 Records test instrument identification numbers and calibration expiration dates, as required.

3.6.4 Initials and dates every test step on the field copy as it is completed next to the step number or on a Data Sheet, when provided. Records test data.

3.6.5 Records exceptions on an exception form. Uses additional exception forms as needed. Notifies the Test Director at time the exception is made.

3.6.6 Signs Execution and Test Approval page when test has been performed.

3.6.7 After test is finished, assigns alpha numeric page numbers to added data sheets and exception forms. Records page numbers in the Table of Contents.

3.6.8 Transfers field copy entries for each step to the Master in ink or type; signs, and dates. Transmits the completed Master to the Test Director for approval signature routing. Transmits the field copy to Construction Document Control for inclusion in the official project file.

3.6.9 Signs exception form when exception has been resolved and transmits to Test Director.

\subsection{TEST OPERATOR}

3.7.1 Performs test under direction of the Test Director.

3.7.2 Provides labor, equipment, and test instruments required for performing tests which have not been designated as being provided by others.

3.7.3 Confirms that all equipment required for performing test will be available at the start of testing.

3.7.4 Signs the Execution and Test Approval page.

3.8 A-E ACCEPTANCE INSPECTION, DESIGN ENGINEER, AND PROJECT MANAGER

3.8.1 Evaluates results.

3.8.2 Signs for A-E Approval on Execution and Test Approval page.

W320014.ATP. 1110

$-6-$

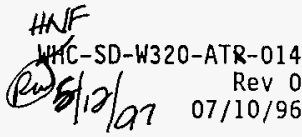


4 CHANGE CONTROL

Required changes to this ATP must be processed on ECNs in accordance with company procedures. If a need for change is discovered in the course of running the test, the test shall be stopped until the ECN is approved. However, this does not prevent the running of another portion of the test unaffected by the change.

$5 \quad$ EXECUTION

5.1 OCCUPATIONAL SAFETY AND HEALTH

Individuals shall carry out their assigned work in a safe manner to protect themselves and others from hazards and to prevent damage to property and environment. Facility line managers shall ensure the safety of activities within their areas to prevent injury, property damage, or interruption of operation. Performance of test activities shall always include safety and health aspects.

These tests involve working near energized equipment, high pressure hydraulics, moving gears, and pistons. All procedural requirements for working near energized equipment shall be followed, and an Energized Electrical Work Permit (KEH-2211.00/WHC-A-6001-687) shall be completed.

5.2 PERFORMANCE

5.2.1 Conduct testing in accordance with ICF KH Procedure CON 3.5 (Performance and Recording of Acceptance Test Procedures).

5.2.2 Perform test following the steps and requirements of this procedure.

5.2.3 As each step in Sections 7 through 10 are completed, the person completing the steps in each Section shall initial and date in the space provided. After each Section is completed, initial and date in the space provided in Section 11.

6.1 GENERAL

Exceptions to the required test results are sequentially numbered and recorded on individual exception forms (KEH-428). This enables case-by-case resolution and approval of each exception.

Errors/exceptions in the ATP itself shall NOT be processed as test exceptions (see Section 4 CHANGE CONTROL).

6.2 RECOROING

6.2.1 Number each exception sequentially as it occurs and record it on an exception form.

6.2.2 Enter name and organization of the individual that identifies each exception. 
6.2.3 Enter planned action to resolve each exception when such determination is made.

\subsection{RETEST/RESOLUTION}

Record the action taken to resolve each exception. Action taken may not be the same as planned action.

6.3.1 When action taken results in an acceptable retest, sign and date Retest Execution and Acceptance section of the exception form.

\subsubsection{When action taken does not involve an acceptable retest, strike out} the Retest Execution and Acceptance section of the exception form.

6.4 APPROVAL AND ACCEPTANCE

The Test Director provides final approvai and acceptance of exceptions by checking one of the following on exception form:

6.4.1 Retest Approved and Accepted: Applicable when Retest Execution and Acceptance section is completed.

6.4.2 Exception Accepted-As-Is: Requires detailed explanation.

6.4.3 Other: Requires detailed explanation.

The Test Director signs and dates the exception form and obtains other approvals, if required.

6.5 DISTRIBUTION

A copy of the approved exception form is distributed to each participant. The signed original is attached to the ATP Master.

7 PREREQUISITES, EQUIPMENT/INSTRUMENTS, AND ABBREVIATIONS

\subsection{PREREQUISITES}

The following conditions shall exist at start of test.

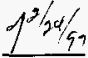

7.1 .1

$24 / 407.1 .2$
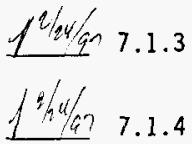

7.1 .4

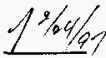

7.1 .5
WHC Project Engineer has been notified 24 hours prior to start of the testing.

Systems and components have been appropriately tagged, in accordance with Drawing $\mathrm{H}-2-818559$, Sh 2 and inspected for compliance with construction documents.

Reference documents (including this ATP) have been verified for correct revision number and outstanding ECNs.

A Prejob Safety Analysis has been prepared and a Prejob Safety Meeting has been conducted.

Wiring for the power feeder to the sluicer hydraulic control skid, SHC-1361, has been continuity tested and meggered.

W320014.ATP.1110

$-8-$

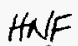

HHT $\mathrm{C}_{7}$ SD-W320-ATR-014

Rev 0

$07 / 10 / 96$ 
7.1.6 Grounding of the sluicer hydraulic power unit, S-1361, has been visually inspected and continuity tested.

folot/g? 7.1.7 The Sluicer Hydraulic Power Unit S-1361 Feeder Breaker MCC-N1/1FB, at Electrical Equipment Skid 241-C-51, is open (OFF position).

$12 / 469$

7.1.8 At the Sluicer Hydraulic Skid, the sluicer disconnect switch is open (OFF position).

12iz4, 7.1.9 Power is available to CB-01 in M0-211.

$11 / 21 / 97$ 7.1.10 All worker safety equipment required to perform test is readily available.

$12 / 24 / a 9$ Voice communications are available between construction Trailer MO-211 and Sluice Pit 241-C-06C.

13/4/97 7.1.12 ATP WHC-SD-W320-ATP-015, C-FARM CCTV SYSTEM, has been completed and CCTV system is operating and focused to view Sluicer S-1361 pan/tilt

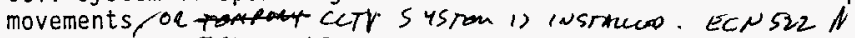

$11 / 2 / 49$ 7.1.13 Tank C-106 sluicer instruments listed in Table 7.1 .13 have been calibrated.

7.2 EQUIPMENT/INSTRUMENTS

Supplied by Test Operator unTess otherwise noted.

7.2.1 Volt-ohmmeter (VOM): $120 / 240$ to $277 / 480 \mathrm{~V}$ ac

Instrument No. $954-45 \cdot 08-005$ Expiration Date 5 _ $28 / 9$ ?

7.2.2 Phase Rotation Meter: No ID number or calibration required.

7.3 ABBREVIATIONS

A A phase voltage or current

B B phase voltage or current

C C phase voltage or current

CB Circuit Breaker

ECN Engineering Change Notice

VI Vendor Information

VOM Volt-ohmmeter

SHC Sluicer Hydraulic Control Unit

MCC Motor Control Center 


\begin{tabular}{|c|c|c|c|}
\hline \multicolumn{4}{|c|}{ DATA SHEET 7.1 .13} \\
\hline \multirow{2}{*}{$\begin{array}{c}\text { INITIAL } \\
\& \\
\text { DATE }\end{array}$} & \multirow{2}{*}{ INSTRUMENT TAG NUMBER } & \multicolumn{2}{|c|}{ VERIFY CALIBRATION } \\
\hline & & CALIBRATED & EXPIRATION \\
\hline$j^{1 / n / 91}$ & $Z E / Z T-13613$ & $6 / 21 / 46$ & $6 / 21 / 47$ \\
\hline f $1 / 2 / 41$ & $Z E / Z T-13614$ & $6 / 21 / 96$ & $6 / 21 / 47$ \\
\hline $11 / 2 / 91$ & $Z I-13613$ & $6 / 21 / 96$ & $6 / 21 / 97$ \\
\hline $1^{1 / n} / q n$ & $\begin{array}{l}\mathrm{ZI}-13614 / Z \mathrm{ZS}-13614 \mathrm{~L} / \\
\mathrm{ZS}-13614 \mathrm{R}\end{array}$ & $6 / 21 / 96$ & $6 / 21 / 47$ \\
\hline
\end{tabular}

\section{END OF SECTION 7}


The following will check electrical services of the sluicer hydraulic power unit at Sluicer Hydraulic Control SHC-1361.

NOTE: If any of the following steps do not perform as stated, stop the test and notify the Test Director.

8.1 PREPARATION

$125 \%$

8.1 .1

Apuctase 2 corst2 $\mathrm{A}$

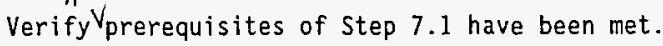

\section{CAUTION: Observe proper electrical safety precautions around energized} equ ipment ( reference WHC-CM-1-10, WKS 15).

\subsection{SLUICER HYDRAULIC POWER UNIT ELECTRICAL SYSTEM CHECK}

$19 / 25 / 47$

8.2 .1

$40 / 25 / 9$

8.2 .2

$12 / 25,57$

8.2 .3

$12 / 25 / 47$

8.2. 4

$\frac{14 / 15 / 97}{\text { Excentions: }}$

8.2 .5

$\frac{14 / 15 / 57}{\text { excostons }} 8.2 .6$

$14 / 15 / 40$

8.2.7

Evespon 7

8.2 .7

NOTE I:

NOTE 2:

At CB-OI in M0-211, verify that power is available at the sluicer control panel.

At vicinity of Sluice Pit $241-\mathrm{C}-06 \mathrm{C}$ and at the combination motor starter (MCC) in SHC-1361, connect the phase rotation meter on feed side of hydraulic pump.

At Bldg 241-C-51, close the Sluicer Feeder Breaker MCC-N1/1FB (ON position).

At SHC-1361, close the sluicer local disconnect switch (ON position).

Verify phase rotation is clockwise (for $A, B, C$ ). If not stop the test and notify the Test Director.

Using the VOM at the MCC measure and verify that all 3 phase-to-phase voltages $\left(V_{A B}, V_{A C}, V_{B C}\right)$ are in the range of 480 to $504 \mathrm{~V}$ ac. If the voltage is not within the specified range, stop the test and notify the Test Director.

Using the VOM, measure the voltage across the secondary of control transformer, and verify the voltage is in the range of 104 to $127 \mathrm{~V} \mathrm{ac}$. If the voltage is not within the specified range, stop the test and notify the Test Director.

The next step will require an independent person to observe hydraulic pump rotation.

At SHC-1361, observe the hydraulic system and verify that no unusual noises and no hydraulic leaks are present in the next step. If unusual noises or hydraulic leaks are present, stop the test and notify the Test Director.

W320014.ATP. 1110 
In trailer M0-211 and on panel CB-01, momentarily set sluicer System Switch HS-13613 to ON position and then back to OFF position. At $S H C-1361$, verify that hydraulic pump rotates in the proper direction (clockwise as viewed from shaft end). If not, $2 / 2510$

\section{2 .9} stop the test and notify the Test Director.

$1^{2 / 2547}$

$12 / 25 / 4 ?$

At 241-C-51, open Sluicer Feeder Breaker MCC-N1/1FB (OFF position).

t $3 / 1 / 477$

8.2 .12

$4^{3 / / 4 / 52}$

Open the Sluicer Local Disconnect Switch (OFF position).

NOTE:

Disconnect and remove the phase rotation meter.

Close Sluicer Local Disconnect Switch (ON position).

Close Sluicer Feeder Breaker MCC-NI/IFB (ON position).

Interlocks to instruments $L S L-1362$ and TSH-1362 have been

previousiy tested by vendor as part of Factory Acceptance Test;

therefore, no further checks are required.

END OF SECTION 8 
The following will check the sluicer pan/tilt controls.

NOTE 1:

NOTE 2:

NOTE 3:

\subsection{PREPARATION}

\section{$1 / 18 / 57 \quad 9.1 .1$ t $\pi / 5 / 97-9.1 .2$}

$29 / 919.1 .3$

$9 / 27 / 8=9.1 .4$

$4 \pi / 210.1 .5$

$1^{2 / 27 / 9 ?} 9.1 .6$

$1^{3 / 14 / 47} 9.1 .7$

$13 / 14 / 42 \quad 9.1 .8$

$\frac{2 / 2 / 97}{12 / 14 / 47} 9.1 .9$
If any of the following steps do not perform as stated, stop the test and notify the Test Director.

At SHC-1361, observe the hydraulic system and verify that no unusual noises and no hydraulic leaks are present during the tests. If unusual noises or hydraulic leaks are present, stop the test and notify the Test Director.

The tolerance for verification of pan and tilt indications is $1^{\circ}$.

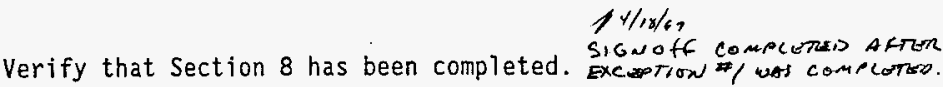

On CB-01, in Trailer M0-211, and on Sluicer Control Panel, test panel lights using pushing to test and verify each light LIT when pressed.

At SHC-1361, verify hydraulic fluid level in the hydraulic reservoir is approximately half full.

Set Sluicer ON/OFF Switch HS-13613 to ON position. Verify Sluicer $0 N$ Light $\mathrm{YL}-13613 \mathrm{~A}$ is LIT and OFF Light $\mathrm{YL}-13613 \mathrm{~B}$ is NOT LIT.

Set Tilt ON/OFF Switch HS-1364 to OFF position. Verify that Tilt ON Light YL-13615A is NOT LIT and Tilt OFF Light YL-13615B is LIT.

Set MAN/AUTO Switch HS-13614 to MAN position. Verify that Auto Light YL-13614A is NOT LIT and MAN Light YL-13614B is LIT.

Verify that Tilt Indicator ZI-13613 indicates $0^{\circ}$. $13 / 1 / 91$

Verify that Pan Indicator ZI-13614 indicates $0^{\circ}$.

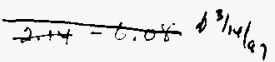

On Pan Indicator ZI-13614, set left Limit Switch ZS-13614L to $-95^{\circ}$ and right Limit Switch ZS-13614R to $95^{\circ}$.

9.2 PAN MANUAL CONTROL

$13 / 14 / 479.2 .1$

On CB-01, bump Joystick ZC-136l to right and left, and verify sluicer nozzle responded accordingly by viewing from the CCTV CP-O2. CO 3221

NOTE 1: Observe sluicer nozzle and assembly closely to see if any movement occurs in response to the movement of the joystick. This may take several operations of the joystick because of entrapped air in the hydraulic system which must be bled out by the inflow of hydraulic fluid. 
NOTE 2: For the succeeding steps of Section 9, observation of sluicer nozzle position shall be performed by viewing CCTV ot $4 P$. ECU522

CAUTION: "Do not maintain joystick position in either position if the slujcer nozzle does not respond, because unexpected movement may result.

$\frac{14(15 / 5)}{\operatorname{excesention} x^{2}} 9.2 .2$

$\frac{(y / 15 / 5)}{\text { Excention }} 9.2 .3$

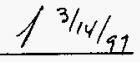

9.2 .4

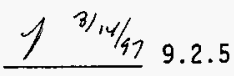

\subsection{TILT CONTROL}

$13 / 14 / 92 \quad 9.3 .1$

$\begin{array}{ll}\frac{13 / 14 / 47}{2} 9.3 .2 \\ \text { of } 3 / 14 / 11 & 9.3 .3\end{array}$

$1^{3 / 14 / 42} 9.3 .4$

NOTE:

$1^{9 / 14 / 97} 9.3 .5$

W320014.ATP.1110
With the sluicer nozzle tilt position at $0^{\circ}$ (straight down), position Joystick ZC-1361 to the right; simultaneously verify the sluicer nozzle rotates to the right and stops, and the Position Indicator Z1-13614 reads incrementally from $0^{\circ}$ to $5^{\circ}, 10^{\circ}, 30^{\circ}$, $60^{\circ}$ and stops at $95^{\circ}$. Bump joystick position to the right several times. Verify that ZI-13614 and sluicer nozzle maintained its position at $95^{\circ}$.

Release Joystick ZC-1361. Verify that Joystick ZC-1361 returns to center, ZI-13614 maintained its last reading of $95^{\circ}$, and the sluicer nozzle has maintained its last position to the right.

Position Joystick $\mathrm{ZC}-1361$ to the left; simultaneously verify that sluicer nozzle rotates to the left and stops, and the Position Indicator ZI-13614 reads incrementally from $95^{\circ}$ to $60^{\circ}, 30^{\circ}, 10^{\circ}$, $5^{\circ}, 0^{\circ},-5^{\circ},-10^{\circ},-30^{\circ},-60^{\circ}$ and stops at $-95^{\circ}$. Bump joystick to the left position several times and verify that ZI-13614 and sluicer nozzle maintained its position at $-95^{\circ}$.

Release joystick. Verify that joystick returns to center, ZI-13614 maintained its last reading of $-95^{\circ}$, and the sluicer nozzle has maintained its last position to the left.

On CB-01, move Joystick $2 C-1361$ up and down; verify that sluicer does not move.

Set sluicer Tilt Control ON/OFF Switch HS-1364 to ON position.

Verify that Tilt ON Light YL-13615A, is LIT and Tilt OFF Light YL-13615B is NOT LIT.

Bump Joystick ZC-1361 up and down, and verify sluicer nozzle responded accordingly.

Observe sluicer nozzle and assembly closely to see if any movement occurs in response to the movement of the joystick. This may take several operations of the joystick because of entrapped air in the hydraulic system which must be bled out by the inflow of hydraulic fluid.

Position joystick upward (pulled back) and start stopwatch; simultaneously verify sluicer nozzle tilted upward from approximately $0^{\circ}$ to and stopped at approximately $90^{\circ}$ position,

- 14 - 


\section{$13 / 14 / 97$}

9.3 .6

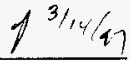

9.3 .7 and the Position Indicator ZI-13613 reads incrementally from $0^{\circ}$ to $20^{\circ}, 50^{\circ}, 75^{\circ}, 85^{\circ}$ and stops at $90^{\circ}$ in approximately 15 seconds. Bump joystick to the up position several times. Verify that ZI-13613 and sluicer nozzle maintained its position at $90^{\circ}$.

Release joystick. Verify that joystick returns to center, ZI-13613 maintained its last reading of $90^{\circ}$, and the sluicer nozzle maintained its last position at $90^{\circ}$.

Position joystick downward and start stopwatch; simultaneously verify sluicer nozzle tilted downward from $90^{\circ}$ horizontal position to and stopped at approximately $-40^{\circ}$, and the Position Indicator ZI-13613 reads incrementally from $90^{\circ}$ to $85^{\circ}, 75^{\circ}, 50^{\circ}$, $20^{\circ}, 0^{\circ},-10^{\circ},-30^{\circ}$ and stops at $-40^{\circ}$ in approximately 22 seconds. Bump joystick to the down position several times. Verify that ZI-13613 and sluicer nozzle maintained its position at $-40^{\circ}$.

Release joystick. Verify that joystick returns to center, ZI-13613 maintained its last reading of $-40^{\circ}$, and sluicer nozzle maintained its last position at $-40^{\circ}$.

\subsection{AUTOMATIC PAN CONTROL}

$13 / 4 / 919.4 .1$

$\int^{3 / 64 / 47} 9.4 .2$

$3 / 14 / 919.4 .3$

$13 / 14 / 47 \quad 9.4 .4$

$13 / 14 / 97 \quad 9.4 .5$

$13 / 14 / 919.4 .6$
On CB-01, set MAN/AUTO Switch HS-13614 to AUTO position; verify that AUTO Light YL-13614A is LIT and MAN Light YL-13614B is NOT IIT.

Verify simultaneously that ZI-13614 indicates a full sweep from $-95^{\circ}$ to $95^{\circ}$ and back to $-95^{\circ}$, and that the sluicer nozzle rotated from left position to right position and back to left position and continues to move.

Position Joystick $Z C-1361$ to the left and the right and verify that there is no affect upon the panning motion of the sluicer nozzle and Position Indicator ZI-13614.

Verify that the Tilt Control Switch $\mathrm{HS}-1364$ is set to ON position, YL-13615A is NOT LIT, and YL-13615B is LIT.

Position Joystick ZC-1361 upward. Simultaneously verify ZI-13613 reads incrementaliy from $-40^{\circ}$ to $-30^{\circ},-10^{\circ}, 0^{\circ}, 20^{\circ}, 50^{\circ}, 75^{\circ}$, $85^{\circ}$ and stops at $90^{\circ}$, and the sluicer nozzle tilts from approximately $-40^{\circ}$ to approximately $90^{\circ}$ and has no affect upon the panning motion.

Set the Tilt Control Switch HS-1364 to OFF position and verify Light $Y L-13615 A$ is LIT and $Y L-13615 B$ is NOT LIT. 

there is no affect upon the panning and tilt motion of the sluicer nozzle and the Position Indicators ZI-13613 and ZI-13614.

pg 16 CHANGE steps 9.4.8-9.4.10 to read as follows:

$$
\text { EC- - } 1+1 / 1 / 1
$$

$13 / 1 / 99.4 .8$ On CB-01, set Man/Auto Switch HS-13614 to Man position.

$13 / 1 / 919.4 .9$ Verify the current sluicer nozzle position is reading between $-60^{\circ}$ and $60^{\circ}$. If not, manually adjust the sluicer nozzle position between $-60^{\circ}$ and $60^{\circ}$.

13/4/97 9.4.10 On ZI-13614, adjust setpoint limits ZS-13614L to $-60^{\circ}$ and ZS-13614R to $60^{\circ}$.

pg 16 ADD steps 9.4.11-9.4.17 to read as follows:

13/14/279.4.11 On CB-01, set Man/Auto switch HS-13614 to Auto position. Verify that ZI-13614 and sluicer nozzle rotates continuously from left to right position between $-60^{\circ}$ and $60^{\circ}$.

13/1r/a>9.4.12 On CB-01, set Man/Auto Switch HS-13614 to Man position.

$11 / 4 / 99^{9.4 .13}$ Verify the current sluicer nozzle position is reading between $-30^{\circ}$ and $30^{\circ}$. If not, manually adjust the sluicer nozzle position between $-30^{\circ}$ and $30^{\circ}$.

Y $3 / / / 9-9.4 .14$ On Zl-13614, adjust setpoint limits ZS-13614L to $-30^{\circ}$ and ZS-13614R to $30^{\circ}$.

$13 / r / 479.4 .15$ On CB-01, set Man/Auto switch HS-13614 to Auto position. Verify that Zl-13614 and sluicer nozzle rotates continuously from left to right position between $-30^{\circ}$ and $30^{\circ}$.

D3/ry/s9.4.16 On CB-01, set Man/Auto Switch HS-13614 to Man position.

11/Y/e29.4.17 On Zl-13614, reset Limit Switches ZS-13614L to $-95^{\circ}$ and ZS-13614R to $95^{\circ}$. 
10 RESTORATION

10.1 SLUICER RESTORATION

$13 / 14 / 47$ 10.1.1 Set MAN/AUTO Switch HS-13614 to MAN position.

$1 \mathrm{~J} / 14 / 91$ 10.1.2 Verify "MAN" Light YL-13614B is LIT.

$1^{3 / 14 / 92} 10.1 .3$ Set Sluicer ON/OFF Switch HS-13613 to OFF position.

$13 / 14 / 91$ 10.1.4 Verify "OFF" Light YL-13613B is LIT.

$13 / r(12) 10.1 .5 \quad \begin{aligned} & \text { At } 241-C-51 \text {, open Sluicer Feeder Breaker MCC-N1/1FB (OFF } \\ & \text { position). }\end{aligned}$

$19 / 4$ (q1 10.1.6 Open sluicer Local Disconnect Switch (OFF position).

END OF SECTION 10 
1) TEST SECTION COMPLETION

Upon completion of the testing steps in each Section, initial and date in the space provided.

\begin{tabular}{|c|c|c|c|}
\hline \multicolumn{4}{|c|}{ TEST COMPLETION WHC-SD-W320-ATP-011 } \\
\hline \multicolumn{2}{|r|}{ PERFORM } & INITIAL & DATE \\
\hline 7 & PREREQUISITES & & \\
\hline 8 & $\begin{array}{l}\text { SLUICER HYDRAULIC CONTROL UNIT SHC-1361 } \\
\text { ELECTRICAL SERVICE }\end{array}$ & & \\
\hline 9 & SLUICER PAN/TILT CONTROLS & & \\
\hline 10 & RESTORATION & & \\
\hline
\end{tabular}

END OF SECTION 11 


\section{HNF \\ Q45)12/97 \\ WHC-SD-W320-ATR-014 kev. \\ C-106 TANK SLUICER CONTROL SYSTEM \\ APPENDIX A \\ EXCEPTIONS}




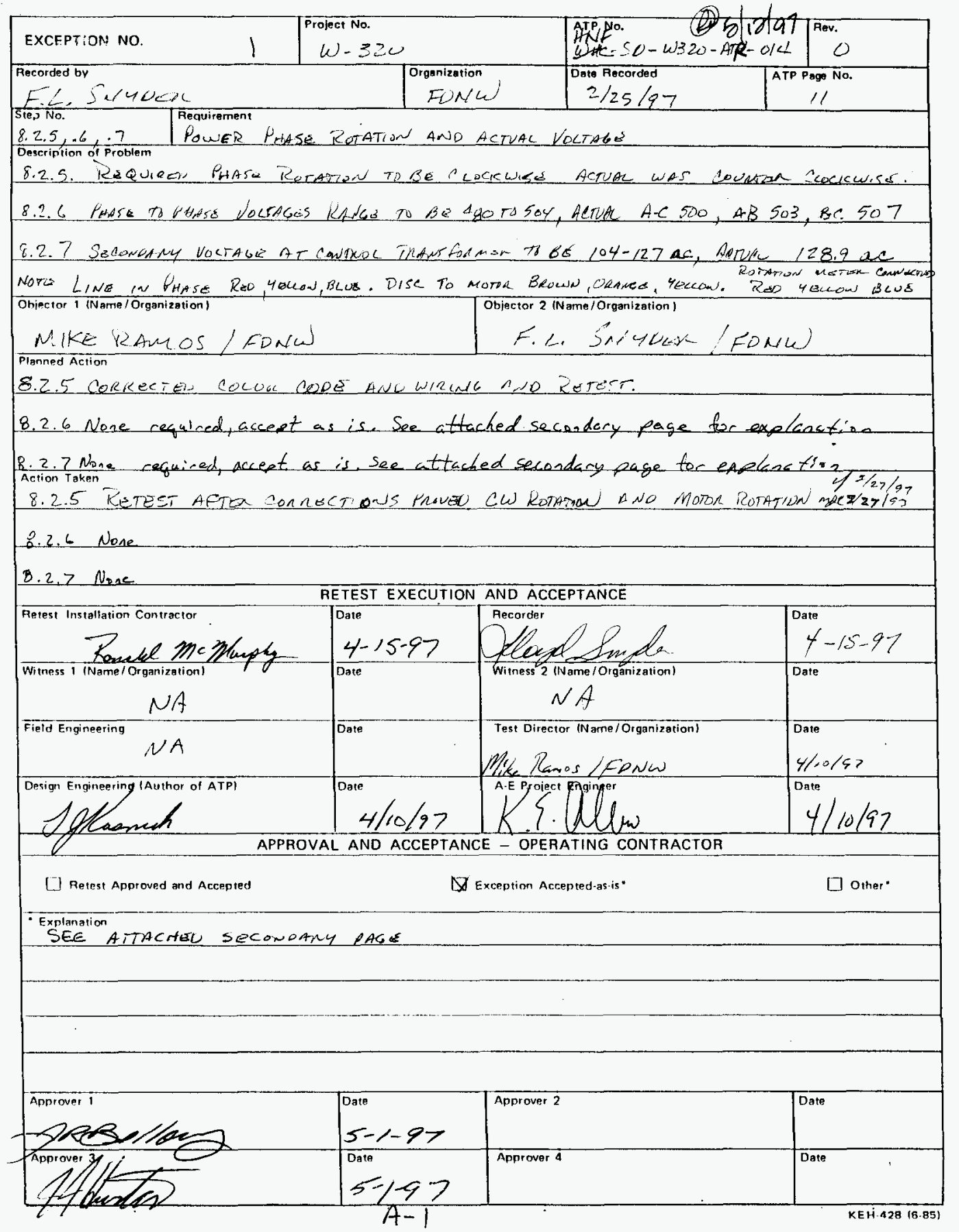




\begin{tabular}{|c|c|}
\hline area & $\nabla$ lanosdd $\forall$ \\
\hline ased & $\tau$ גa八oddd $\forall$ \\
\hline
\end{tabular}

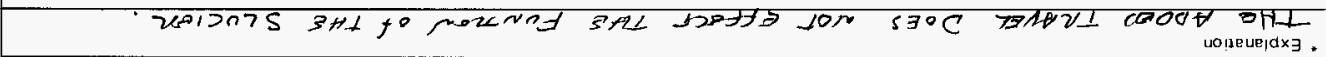

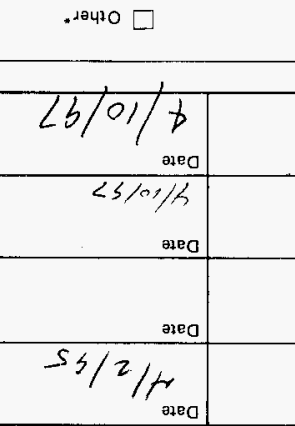

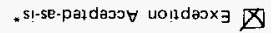

paldaoo $\forall$ pue panosdd $\forall$ saray

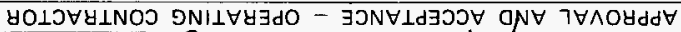
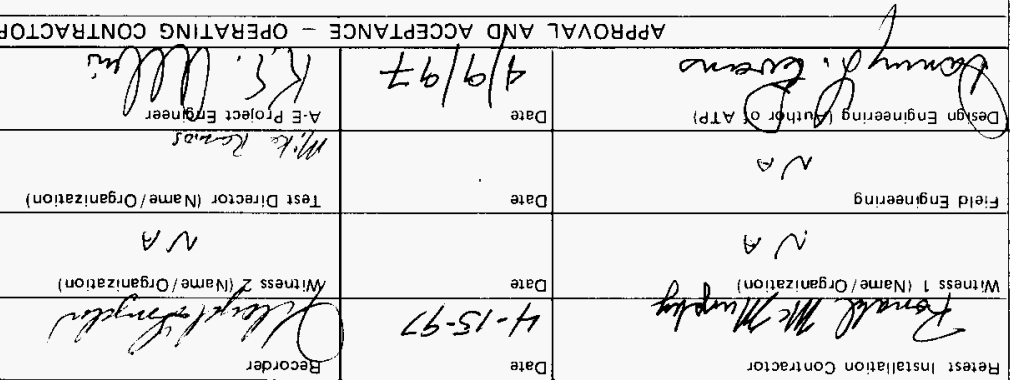
$\exists \supset N \forall \perp d \exists \supset \supset \forall$ aN

- $\operatorname{rom}$

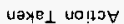

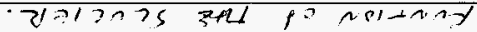

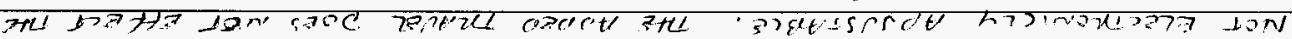

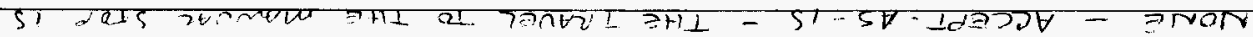
$\bmod / \operatorname{son} 321 \mathrm{~m}$

\section{(.1) 30ल4x 328}

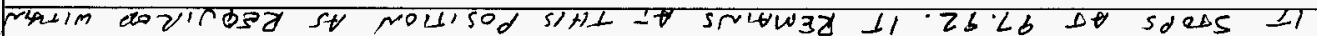

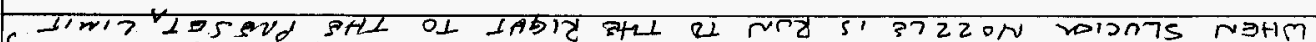
fromm anderethy go purse

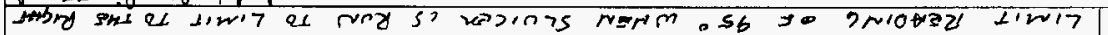

wajqond to volidusaga

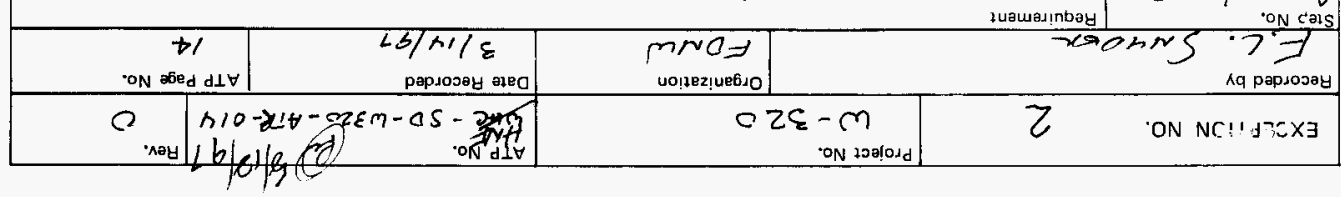


Continuation of Planned Action

8.2.6 Excessive voltage measure on one phase of three phase system will not adversely effect or damage equipment. Electrical Utilities Dept. sets voltage levels for Hanford power distribution system.

8.2.7 A recorded high secondary side voltage on the slicer Hydraulic control transformer will not effect or damage equipment. A high secondary side voltage was due to the excessive voltage reading measured on one phase in step 8.2.6. 